\title{
A role of vitamin $D$ in low-intensity chronic inflammation and insulin resistance in type 2 diabetes mellitus?
}

\author{
Mario Flores \\ Centro de Investigación en Nutrición y Salud, Instituto Nacional de Salud Publica \\ (National Institute of Public Health), Cuernavaca, Mexico
}

\begin{abstract}
Evidence from different directions, including observational and experimental studies, points to a role of vitamin D status in low-intensity chronic inflammation and insulin resistance in type 2 diabetes mellitus (T2DM). It has been recognised that insulin resistance and low-intensity chronic inflammation are risk factors for T2DM. Thus, vitamin D status can be implicated in the aetiology of TD2M. It is suggested that the relationship between vitamin D and low-intensity chronic inflammation and insulin resistance in T2DM can be mediated in part by the immune-modulating properties of the active form of vitamin $\mathrm{D}\left(1-\alpha, 25\right.$-dihydroxyvitamin $\mathrm{D}_{3}$; $1,25(\mathrm{OH})_{2} \mathrm{D}_{3}$ ), which is able to down regulate the production of pro-inflammatory cytokines particularly TNF- $\alpha$, and IL-6. However, an association between vitamin D status and these features, which is independent of BMI, has been also reported. Non-calcaemic effects of vitamin $\mathrm{D}$ can be associated with health outcomes other than those traditionally attributed to the vitamin.
\end{abstract}

Vitamin D: Type 2 diabetes: Insulin resistance: C-reactive protein

\section{Introduction}

Various studies have shown a role of vitamin D in glucose homeostasis. In rats, 1- $\alpha, 25$-dihydroxyvitamin $\mathrm{D}_{3}$ $\left(1,25(\mathrm{OH})_{2} \mathrm{D}_{3}\right)$ plays an essential role in normal insulin secretion, irrespective of dietary energy intake and serum $\mathrm{Ca}$ levels (Kadowaki \& Norman, 1985). Vitamin D deficiency is also associated with poor $\beta$ cell function, and the restoration of vitamin D normalises glucose metabolism (Kadowaki \& Norman, 1985). Animal studies have demonstrated lower levels of vitamin $\mathrm{D}$ in a type 2 diabetes mellitus (T2DM) model, compared with controls (Ishimura et al. 1995).

In human subjects, low vitamin $\mathrm{D}$ concentrations have been associated with glucose intolerance and hyperinsulinaemic responses in oral glucose tolerance tests (Chiu et al. 2001a). Clinical studies have demonstrated a positive correlation between circulating vitamin D (25-hydroxyvitamin $\mathrm{D} ; 25(\mathrm{OH}) \mathrm{D})$ levels and insulin sensitivity (Chiu et al. 2001a, 2004). There is also experimental evidence of a reduction in insulin resistance, and improvement in glucose levels in oral glucose tolerance tests after vitamin D supplementation in diabetic subjects (Borissova et al. 2003; Zittermann, 2003). A recent study in a multi-ethnic sample of $>6000$ adults who participated in the Third National Health and Examination Survey
(NHANES III) in the USA reported an inverse association between vitamin $\mathrm{D}$ status, diabetes and insulin resistance (Scragg et al. 2004).

One cannot evaluate the role of vitamin D in low-intensity chronic inflammation and insulin resistance in T2DM without taking into consideration that vitamin $\mathrm{D}$ status is related to adiposity (Arunabh et al. 2003; Parikh et al. 2004), and that adiposity is in turn related to both chronic inflammation and insulin resistance (Bays et al. 2004). These relationships, which are described below, are shown in Fig. 1.

\section{Adiposity, low-intensity chronic inflammation and insulin resistance}

There is increasing evidence from clinical and observational studies that a systemic, sub-clinical, low-intensity inflammatory reaction not only co-exists, but also precedes the development of T2DM (Schmidt et al. 1999; Barzilay et al. 2001; Pradhan et al. 2001; Ford, 2002; Freeman et al. 2002; Han et al. 2002; Vozarova et al. 2002; Engström et al. 2003). A characteristic of this inflammatory reaction is the presence of elevated serum acute-phase proteins and proinflammatory cytokines (Schmidt et al. 1999; Barzilay et al. 2001; Pradhan et al. 2001; Ford, 2002; Freeman et al. 2002; 


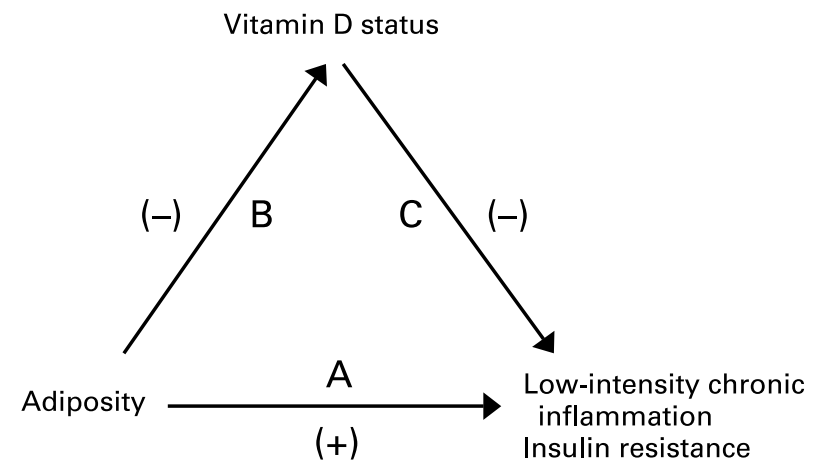

Fig. 1. Relationships among adiposity, vitamin $D$ status, low-intensity chronic inflammation, and insulin resistance. Increased adiposity, as usually seen in type 2 diabetes mellitus (i.e. increased BMI and body fat mass), is positively associated with low-intensity chronic inflammation (i.e. elevated C-reactive protein (CRP) concentrations) and insulin resistance. This is likely to be related to the release of proinflammatory cytokines by the adipose tissue, particularly TNF- $\alpha$ and IL-6, which are known to cause insulin resistance and promote the synthesis of CRP by the liver (A). In turn, adiposity is negatively associated with vitamin $D$ status, due to storage of vitamin $D$ in the adipose tissue (B). Vitamin D status is negatively associated with both low-intensity chronic inflammation and insulin resistance. It is proposed that this can be related to down regulation of the production of pro-inflammatory cytokines by the active form of vitamin $D\left(1,25(\mathrm{OH})_{2} \mathrm{D}_{3}\right)$ in immune cells infiltrating the adipose tissue $(C)$

Han et al. 2002; Vozarova et al. 2002; Engström et al. 2003). These observations have led to the hypothesis of a pathological role of an ongoing cytokine-induced acutephase response in the pathogenesis of T2DM (Yudkin et al. 1999; Pickup, 2004). The inflammatory markers that have shown a strongest predictive capacity in the development of T2DM are C-reactive protein (CRP) and IL-6 (Schmidt et al. 1999; Yudkin et al. 1999; Barzilay et al. 2001; Pradhan et al. 2001; Ford, 2002; Freeman et al. 2002; Han et al. 2002; Vozarova et al. 2002; Engström et al. 2003; Pickup, 2004). It is important to note that CRP can be considered to be a surrogate marker for the activity of the pro-inflammatory cytokines IL-6 and TNF- $\alpha$, since these cytokines act synergistically to promote the synthesis of CRP and other acute-phase proteins by the liver (Koj et al. 1988; Gewurz et al. 1995; Pepys \& Hirschfield, 2003).

Epidemiological studies have shown that TNF- $\alpha$, CRP and IL-6 are positively correlated with BMI and percentage body fat (Das, 2001; Bermudez et al. 2002; Pittas et al. 2004). CRP levels have been found to be elevated $(>3.0 \mathrm{mg} / \mathrm{l})$ both in overweight and in obese individuals, and in subjects with T2DM (Das, 2001; Bermudez et al. 2002; Pittas et al. 2004). The strong positive correlation between adiposity and CRP levels may reflect in part the fact that adipocytes are the source of a large proportion of baseline IL- 6 as well as TNF- $\alpha$ (Kershaw \& Flier, 2004; Pittas et al. 2004). It has also been observed that macrophages infiltrate adipose tissue in obese individuals, contributing to the release of pro-inflammatory cytokines (Weisberg et al. 2003). These cytokines - particularly TNF- $\alpha$, IL- 6 and IL- 1 - are able to cause insulin resistance in adipocytes (Xu et al. 2003). It is known that insulin is a potent inhibitor of lipolysis and restrains the release of NEFA from the adipocyte by inhibiting the enzyme lipoprotein lipase (Bays et al. 2004). Thus, insulin resistance in adipocytes can lead to the release of large amounts of NEFA (Xu et al. 2003; Bays et al. 2004). Chronically elevated plasma NEFA, concentrations can lead to insulin resistance in muscle and liver by impairing tyrosine phosphorylation of insulin receptor substrate (IRS)-1 (Xu et al. 2003; Bays et al. 2004).

According to recent studies, both lipid-lowering agents (statins) and angiotensin-converting-enzyme inhibitors seem to have anti-inflammatory properties, and findings suggest that they may reduce the risk of diabetes (Yusuf et al. 2000; Freeman et al. 2001). Additionally, insulin-sensitising agents, such as thiazolidinediones (Jiang et al. 1998), as well as physical exercise (Smith et al. 1999) also appear to have anti-inflammatory properties. Recent studies on animal models suggest that salicylates can prevent obesity and dietinduced insulin resistance by down regulation of the inhibitor of $\kappa \mathrm{B}$ kinase- $\beta$ (IKK- $\beta$ ) activity (Yuan et al. 2001). IKK- $\beta$ can induce insulin resistance by promoting serine phosphorylation of IRS-1 and subsequent impairment of insulin signalling (Stevenson et al. 1999). In agreement with this hypothesis, an experimental study in T2DM patients, who received high-dose aspirin (about $7 \mathrm{~g} / \mathrm{d}$ for 2 weeks), showed an improvement of fasting and postprandial hyperglycaemia and glucose disposal by 19 to $25 \%$ (Hundal et al. 2002).

A recent study in fifty obese and fifty age-matched, normal-weight premenopausal women (Esposito et al. 2003) demonstrated a significant association between lower serum concentrations of the anti-inflammatory cytokine IL10 and the metabolic syndrome (Beutler et al. 1985), independent of age and body weight. It is known that individuals with the metabolic syndrome are at increased risk of developing T2DM (Han et al. 2002). The same study showed that after 12 months of a lifestyle programme, there was a decrease in body weight, which was associated with a significant decrease in IL-6, CRP, and IL-10 levels in obese women without the metabolic syndrome. In this study, increasing circulating levels of IL10 were observed in obese women without the metabolic syndrome. This presumably tends to limit the chronic inflammatory state associated with obesity, as IL-10 down regulates the production of pro-inflammatory cytokines. However, the contrary - i.e. low IL-10 levels - was observed in women with the metabolic syndrome (Esposito et al. 2003). In summary, these studies suggest that reducing inflammation may have beneficial effects on insulin resistance.

\section{Metabolic effects of pro-inflammatory cytokines}

The metabolic effects of IL- 1 and TNF- $\alpha$ - two of the main pro-inflammatory, Th1 cytokines - are remarkable. These cytokines are able to inhibit the enzyme lipoprotein lipase, and thus can be conducive to elevated levels of VLDL and hypertriacylglycerolaemia (Beutler et al. 1985; Beutler \& Cerami, 1985; Tracey \& Cerami 1990). In addition, they exert important effects on glucose and energy metabolism. It has been observed that the action of IL-1 in the liver produces dislypidaemia, with elevation of VLDL and reduction of HDL, similar to that observed in the metabolic 
syndrome (Beutler \& Cerami, 1985). Other effects of stimulation with TNF- $\alpha$ can lead to metabolic changes of the kind observed in the metabolic syndrome, such as hypertriacylglycerolaemia, redistribution of adipose tissue and insulin resistance (Beutler et al. 1985; Beutler \& Cerami, 1985; Tracey \& Cerami, 1990).

It has been demonstrated experimentally both in animals and human subjects that the administration of IL-6 induces gluconeogenesis, which leads to hyperglycaemia and compensatory hyperinsulinaemia (Stevenson et al. 1999; Yuan et al. 2001). Circulating IL-6 levels correlated positively with circulating triacylglycerol levels in subjects who were otherwise normal and in no acute distress. Moreover, polymorphisms in the promoter region of the IL-6 gene results in constitutively higher circulating IL-6 levels, as well as higher circulating triacylglycerol but not cholesterol levels (Fernandez-Real et al. 2000). It has been suggested that in the basal, healthy state IL-6 may affect triacylglycerol levels by decreasing lipoprotein lipase activity (Papanicolaou, 2000).

Recently, it has been demonstrated that IL-6 inhibits insulin receptor signal transduction by inducing a family of negative signal transducers (SOCS), which interact directly with insulin receptors (Senn et al. 2002). Moreover, IL-6 inhibits the effect of insulin in rat hepatocytes and in human liver cancer cells HepG2 (Senn et al. 2002). There is evidence suggesting that the metabolic effects of TNF- $\alpha$ could be mediated by its capacity of inducing IL- 6 production and promoting the expression of IL-6 receptor in the liver and muscle (Cheung et al. 1998). These cytokines, which are part of the immune system, can be acting as a link between metabolic and immune processes (Pittas et al. 2004). The metabolic effects of these proinflammatory cytokines have motivated researchers to consider them as potential therapeutic targets.

In a study to test for a causative role of IL-6 in insulin resistance in vivo it was shown that treatment by IL-6 reduced insulin-dependent autophosphorylation of IRS-1 and IRS-2 (Klover et al. 2003). Both acute (90 min) and $5 \mathrm{~d}$ IL-6 exposure resulted in significant impairment of early insulin signalling events in the liver of treated mice, compared with controls. Importantly, circulating exogenous IL-6 levels only increased basal levels by 30-50\%, similar to increases observed in human obesity (Klover et al. 2003). In an in vitro study, the acute $(10-60 \mathrm{~min})$ and long-term $(1-24 \mathrm{~h})$ effects of IL-6 and TNF- $\alpha$ were assessed in differentiated 3T3-L1 cells (Rotter et al. 2003). Both IL-6 and $\mathrm{TNF}-\alpha$ significantly reduced the mRNA and protein levels of IRS- 1 as well as GLUT-4 and PPAR- $\gamma$. It was concluded that IL- 6 and TNF- $\alpha$ exert long-term inhibitory effects on the expression levels of key signalling molecules for insulin (Rotter et al. 2003). In another study, the effects of $4 \mathrm{~h}$ treatment of IL- 6 on insulin action were examined in awake mice during a $2 \mathrm{~h}$ hyperinsulinaemic-euglycaemic clamp (Higashimori et al. 2003). Insulin-stimulated wholebody glycolysis and glycogen and lipid synthesis were decreased by 30 and $10 \%$, respectively, with IL-6. Similarly, IL-6 treatment reduced insulin-stimulated skeletal muscle glycolysis and glycogen synthesis by 50 and $20 \%$, respectively. These defects in insulin action were secondary to decreases in IRS-1 PI 3-kinase and protein C kinase activity in skeletal muscle, following IL-6 treatment (Higashimori et al. 2003).

Contrary to the metabolic effects of IL-6 and other proinflammatory cytokines, there is experimental evidence of anti-diabetogenic effects of IL-10, which provides insight into a novel mechanism by which anti-inflammatory cytokines may prevent insulin resistance (Kim et al. 2003). In an in vivo study, the effects of $2 \mathrm{~h}$ pre-treatment of IL-10 on lipid-induced and IL-6-induced insulin resistance were examined in awake mice during a $2 \mathrm{~h}$ hyperinsulinaemic-euglycaemic clamp (Kim et al. 2003). Insulin-stimulated IRS-1 associated PI 3-kinase activities in skeletal muscle were reduced by 60 and $40 \%$ following lipid and IL-6 treatment, respectively. IL-10 pre-treatment prevented both lipid-induced and IL-6-induced reduction in skeletal muscle PI 3-kinase, thus preventing insulin resistance in skeletal muscle (Kim et al. 2003).

\section{Adiposity and vitamin D status}

It has been shown that vitamin $\mathrm{D}$ status has a negative correlation with BMI and body fat mass, and obesity is associated with alterations in the vitamin D endocrine system (Arunabh et al. 2003; Parikh et al. 2004). In a study in 410 healthy women (mean age 47.6 (SD 14.8) years; mean BMI $\left.23.9(\mathrm{SD} 2.9) \mathrm{kg} / \mathrm{m}^{2}\right)$ the correlation between serum $25(\mathrm{OH}) \mathrm{D}$ and percentage of body fat was -0.13 $(P=0.013)$, after adjusting for race, age, season, and dietary vitamin D intake (Arunabh et al. 2003). In another study in 302 healthy adults (154 obese; mean BMI $37.3(\mathrm{SD} 5.8) \mathrm{kg} / \mathrm{m}^{2}$, and 148 non-obese; mean BMI $\left.25.6(\mathrm{sD} 2.9) \mathrm{kg} / \mathrm{m}^{2}\right)$, serum $25(\mathrm{OH}) \mathrm{D}$ was negatively correlated with BMI $(r-0.40 ; P<0.0001)$ and body fat mass $(r-0.41 ; P<0.0001)$ (Parikh et al. 2004). It is thought that obesity-associated vitamin D insufficiency is related to decreased availability of vitamin D from cutaneous and dietary sources because of its deposition in the adipose tissue (Worstman et al. 2000; Arunabh et al. 2003; Parikh et al. 2004).

A high prevalence of hypovitaminosis $\mathrm{D}$ has been reported in women with T2DM, who also had a higher BMI compared with controls (Isaia et al. 2001). In a sample of 6228 individuals aged $\geq 20$ years from NHANES III, an inverse relationship between BMI and serum 25(OH)D was observed, after adjusting for confounders (Scragg et al. 2004).

\section{Vitamin D status, low-intensity chronic inflammation and insulin resistance}

Vitamin D deficiency has been correlated with circulating markers of inflammation in adult subjects (Timms et al. 2002). In a study carried out in fifty-four British adults of Bangladeshi origin, aged 35-65 years, free of known diabetes, hypertension or other ongoing illness, who were vitamin D deficient (baseline 25(OH)D $<11 \mathrm{ng} / \mathrm{ml}$ ) (Timms et al. 2002), CRP concentrations were inversely correlated to vitamin D status, and serum $25(\mathrm{OH}) \mathrm{D}$ was an independent determinant of CRP at baseline. In the aforementioned study on British adults of Bangladeshi origin, fifty-four vitamin D-deficient subjects were 
randomised and given either a 'high' dose (1250 $\mu \mathrm{g}$; $50000 \mathrm{IU}$ ) or a 'low' dose (12.5 $\mu \mathrm{g}$; 500 IU) of a depot (oily) injection of cholecalciferol, every 3 months, during 1 year. After follow-up, there was an increase in vitamin D repletion by $100 \%$, which was similar in both treatment groups (baseline 25(OH)D mean $8.55(\mathrm{SD} 2.47) \mathrm{ng} / \mathrm{ml}$; after supplementation 14.05 (SD 4.9) $\mathrm{ng} / \mathrm{ml})$. Baseline CRP was on average $6 \cdot 12$ (SD 5.87) $\mathrm{mg} / \mathrm{l}$, and was not statistically different between treatment groups. However, the reductions in CRP were greater in the 'high' than in the 'low' treatment group (39.65 v. $4.8 \%$, respectively; $P<0.05)$. The authors concluded that vitamin D deficiency is associated with elevated CRP concentrations, which are correctable by supplementation (Timms et al. 2002).

A study carried out in California, in 126 glucosetolerant, young adults (mean age 26 (SD 6) years), with no evidence or history of chronic or acute illness, showed a positive correlation between $25(\mathrm{OH}) \mathrm{D}$ serum levels and insulin sensitivity $(r 0.2469 ; P=0.0007)$, after controlling for sex, BMI, age, ethnicity, and systolic blood pressure (Chiu et al. 2004). In the same study, the correlation between $25(\mathrm{OH}) \mathrm{D}$ and first-phase insulin secretion was $-0.2513(P=0.0045)$, and $-0.3487(P=0.0001)$ with second-phase insulin secretion. Notably, these relationships were observed within the whole spectrum of $25(\mathrm{OH}) \mathrm{D}$ levels, even among individuals with $25(\mathrm{OH}) \mathrm{D}$ concentrations between 50 and $100 \mathrm{ng} / \mathrm{ml}$, and thus were not strictly related to vitamin D deficiency. In this study, serum $25(\mathrm{OH}) \mathrm{D}$ had a negative correlation with plasma glucose concentration during a standard $75 \mathrm{~g}$ oral glucose tolerance test at $60 \mathrm{~min}(r-0.2878 ; P=0.0011)$, at $90 \mathrm{~min}$ $(r-0.2872 ; P=0.0011)$, and at $120 \mathrm{~min}(r-0.2988$; $P=0 \cdot 0007$ ) (Chiu et al. 2004). Individuals with vitamin D deficiency $-25(\mathrm{OH}) \mathrm{D}$ below $20 \mathrm{ng} / \mathrm{ml}$ - had a higher risk of insulin resistance and a higher risk for the metabolic syndrome, compared with individuals without vitamin D insufficiency (relative risk 2.72; $P=0.0097$ ). Surprisingly, $37 \%$ of the study subjects had serum $25(\mathrm{OH}) \mathrm{D}$ below $20 \mathrm{ng} / \mathrm{ml}$ (Chiu et al. 2004).

In a study in 187 overweight adults (mean BMI $\left.33.4(\mathrm{SD} 6 \cdot 8) \mathrm{kg} / \mathrm{m}^{2}\right)$ the relationships between cacitriopic hormones and insulin sensitivity were examined (Parikh et al. 2003). In a multiple regression model controlling for body fat mass, race, age and sex, serum $25(\mathrm{OH}) \mathrm{D}$ was negatively correlated $(r-0.19 ; \quad P<0.014)$ with Homeostasis Model Assessment for Insulin Resistance, and positively correlated $(r$ 0.264; $P=0.002)$ with Quantitative Insulin Sensitivity Check Index. Intact parato-hormone was positively correlated ( $r$ 0.276; $P=0.0002)$ with Homeostasis Model Assessment for Insulin Resistance, and negatively correlated $(r-0.23$; $P=0.0026)$ with Quantitative Insulin Sensitivity Check Index (Parikh et al. 2003).

In a recent report from NHANES III, in which serum $25(\mathrm{OH}) \mathrm{D}$ levels were assessed in a multi-ethnic sample of 6228 adults, an inverse association between quartiles of serum 25(OH)D and diabetes was found (Scragg et al. 2004). In that study, a fourfold reduction in diabetes risk was observed in non-Hispanic whites who were at the highest quartile of serum $25(\mathrm{OH}) \mathrm{D}$ ( $\geq 81.0 \mathrm{nmol} / \mathrm{l})$, compared with those in the lowest quartile (serum $25(\mathrm{OH}) \mathrm{D}<44.0 \mathrm{nmol} / \mathrm{l}$ ), after adjusting for age, sex, BMI, leisure time physical activity and seasonality (Scragg et al. 2004). A similar trend was observed in Mexican-Americans. These analyses excluded cases with known, diagnosed diabetes (Scragg et al. 2004).

Experimental studies of vitamin D treatment and glucose homeostasis are scarce, usually involve a small number of subjects, use a wide range of treatment regimens, and include different morbid conditions. Despite these dificulties, a recent review (Zittermann, 2003) presented evidence from seven studies in which insulin and glucose response to treatment with vitamin D was assessed. A reduction in blood glucose and insulin levels was observed in five of these studies (Zittermann, 2003). The age of the patients ranged from 17 to 66 years, and duration of treatment ranged from $2 \mathrm{~h}$ (intravenous infusion) to 5 months. Doses of vitamin D administered ranged from $0.75 \mu \mathrm{g}$ calcitriol/d to $2500 \mu \mathrm{g}$ vitamin D. Reductions in blood glucose ranged between 0.8 and $1.6 \mathrm{mmol} / 1$ after a glucose tolerance test (Zittermann, 2003). However, in one study in which subjects received a single injection of $2500 \mu \mathrm{g}$ vitamin $\mathrm{D}$, an increase of $1.8 \mathrm{mmol} / \mathrm{l}$ in blood glucose was observed (Boucher et al. 1995).

A study of vitamin D supplementation in ten women with T2DM and seventeen non-diabetic age- and BMI-matched non-supplemented controls (Borissova et al. 2003) showed a non-significant decrease of $21 \%$ in insulin resistance, after 1 month of receiving $33.3 \mu \mathrm{g}$ (1332 IU) of cholecalciferol. A significant increase of $34.3 \%$ on first-phase insulin secretion was observed in the treatment group $(P<0 \cdot 018$; Borissova et al. 2003).

\section{Immune-regulating effects of vitamin D: plausible mechanism for its actions on low-intensity chronic inflammation and insulin resistance}

Most of the actions of the active form of vitamin D $\left(1,25(\mathrm{OH})_{2} \mathrm{D}_{3}\right)$ are mediated by the intracellular vitamin $\mathrm{D}$ receptor (VDR), a ligand-activated transcription factor, which is a member of the steroid-thyroid hormone receptor family (DeLuca \& Zierold, 1998). VDR forms a heterodimer with the retinoid $\mathrm{X}$ receptor, and this complex regulates the expression of target genes by binding to vitamin D-responsive elements in their promoter regions (DeLuca \& Zierold, 1998). Recent studies have shown a linkage between VDR and the immune system, with the presence of VDR in several immune cells, such as monocytes, macrophages, and activated $\mathrm{T}$ and $\mathrm{B}$ lymphocytes (O'Kelly et al. 2002; Pichler et al. 2002; Matheu et al. 2003). Interference with cytokine production of monocytes and lymphocytes seems to be a key mechanism by which $1,25(\mathrm{OH})_{2} \mathrm{D}_{3}$ interacts with the immune system (Pichler et al. 2002; Mahon et al. 2003). Importantly, VDR is present in the adipose tissue (Kershaw \& Flier, 2004).

In addition to its well-known bone and $\mathrm{Ca}$ - and P-related metabolic functions, the active form of vitamin D $\left(1,25(\mathrm{OH})_{2} \mathrm{D}_{3}\right)$ is an important immune-system regulator (Cantorna et al. 2004). Vitamin D has been shown to inhibit cell proliferation and cytotoxic T-cell function in mixed lymphocyte cultures. When added to mitogen-stimulated PMBC, $1,25(\mathrm{OH})_{2} \mathrm{D}_{3}$ decreases proliferation, immunoglo- 
bulin synthesis and cytokines, including IL-1, IL-2, IL-6, TNF- $\alpha$, and interferon- $\gamma$ (Lemire, 1995; Becker et al. 2002; Lagraine \& Lebranchu, 2003). The observation that $1,25(\mathrm{OH})_{2} \mathrm{D}_{3}$ inhibits the Th1-specific cytokines IL-12 and interferon- $\gamma$ led to the hypothesis that its immunosuppressive properties were achieved mainly by regulation of Th1 cells (Lemire et al. 1995). However, it has been found that $1,25(\mathrm{OH})_{2} \mathrm{D}_{3}$ not only inhibits the synthesis of interferon- $\gamma$, IL-2 and IL-12 production by monocytes, but it also increases synthesis of IL-4, IL-5 and IL-10 (Long \& Santos, 1999). The receptor for IL-10 has also been found to be inducible up to 10-fold in $\mathrm{HaCaT}$ cells on exposure to $1,25(\mathrm{OH})_{2} \mathrm{D}_{3}$. Overall, these findings indicate that this hormone inhibits the Th1 response and may promote a Th2 response (Long \& Santos, 1999). It has been reported that administration of $1,25(\mathrm{OH})_{2} \mathrm{D}_{3}$ suppressed the incidence of diabetes in NOD mice, probably by modulating the Th1Th2 cytokine balance in the pancreatic lesion towards a Th2 profile (Mathieu et al. 1992; Adorini, 2003).

There is experimental evidence showing that $1,25(\mathrm{OH})_{2} \mathrm{D}_{3}$ can down regulate IL-6 production. In human skin fibroblasts and epidermal keratinocytes stimulated with sulfur mustard, $1,25(\mathrm{OH})_{2} \mathrm{D}_{3}$ suppressed IL-6 secretion by $82 \%$ (Arroyo et al. 2003). In this study, stimulation of human skin fibroblasts with sulfur mustard $\left(10^{-4} \mathrm{M}\right.$ for $24 \mathrm{~h}$ at $37^{\circ} \mathrm{C}$ ) resulted in approximately a five-times increase in the secretion of IL-6, and over a ten-times increase for IL-8, which was inhibited by $1,25(\mathrm{OH})_{2} \mathrm{D}_{3}$, at $\leq 10^{-9} \mathrm{M}$. $1,25(\mathrm{OH})_{2} \mathrm{D}_{3}$ also suppressed IL- 8 secretion by five times and IL-6 secretion by four times on sulfur mustardstimulated human epidermal keratinocytes at concentrations $\leq 10^{-9} \mathrm{M}$. The effect of $1,25(\mathrm{OH})_{2} \mathrm{D}_{3}$ on both IL- 6 and IL-8 was dose-dependent (Arroyo et al. 2003).

Recently, it has been reported that $1,25(\mathrm{OH})_{2} \mathrm{D}_{3}$ decreases DNA binding of NF- $\mathrm{BB}$ in human fibroblasts (Harant et al. 1998). The partial inhibition of NF-кB DNA binding by $1,25(\mathrm{OH})_{2} \mathrm{D}_{3}$ is dependent on de novo protein synthesis, suggesting that $1,25(\mathrm{OH})_{2} \mathrm{D}_{3}$ may regulate expression of cellular factors that contribute to reduced DNA binding of NF-кB (Harant et al. 1998, 2000). The ability of $1,25(\mathrm{OH})_{2} \mathrm{D}_{3}$ to inhibit NF- $\mathrm{B}$ activity in cell types involved in inflammation has contributed to the notion of using $1,25(\mathrm{OH})_{2} \mathrm{D}_{3}$ as an anti-inflammatory agent (Harant et al. 1998, 2000; Arroyo et al. 2003).

The effect of vitamin D on the immune system particularly on animal models of autoimmune and allergic disease - has been reviewed recently (Cantorna et al. 2004). Evidence indicates that the effect of treatment with $1,25(\mathrm{OH})_{2} \mathrm{D}_{3}$ is consistent with inhibition of Th1 cells and induction of Th2 cells (Cantorna et al. 2004). It is worth noting that, while $1,25(\mathrm{OH})_{2} \mathrm{D}_{3}$ has been known as an immunosuppresive agent, mostly for its role in allograft survival, it has shown no effect on infectious disease susceptibility in mice at doses used to improve allograft survival (Cantorna et al. 2004).

Of the greatest importance in the context of an adipocytokine-induced process of inflammation and insulin resistance in T2DM is that macrophages - as well as dendritic cells - not only express VDR, but also express the enzyme $1 \alpha$-hydroxylase (Hewison et al. 2004). This gives them the ability to synthesise $1,25(\mathrm{OH})_{2} \mathrm{D}_{3}$ in the presence of substrate (25(OH)D) (Hewison et al. 2004). Thus - at least theoretically - macrophages infiltrating the adipose tissue in obese individuals could be able to modulate the release of pro-inflammatory cytokines in a paracrine fashion, if circulating $25(\mathrm{OH}) \mathrm{D}$ is available in adequate concentrations.

\section{Conclusion}

Evidence from different directions points to a protective role of vitamin D on low-intensity chronic inflammation and insulin resistance in T2DM. It is suggested that this role can be related - at least in part - to the immune-modulating actions of $1,25(\mathrm{OH})_{2} \mathrm{D}_{3}$, which can down regulate the production of pro-inflammatory cytokines by immune cells. However, it is not known yet if this process can take place within the adipose tissue, which seems to be implicated in the development of systemic chronic inflammation and insulin resistance. It is to be noted that an inverse association between vitamin $\mathrm{D}$ status and insulin resistance has been observed in a sample of adult participants in the NHANES, which persisted after controlling for BMI (Scragg et al. 2004). More studies are needed to clarify these issues.

It is widely recognised that, on one hand, insulin resistance is a major feature of T2DM (Reaven, 1988), while, on the other hand, low-intensity chronic inflammation is related to the development of T2DM and to its cardiovascular complications (Bermudez et al. 2002; Pickup, 2004). Thus, vitamin D status can be implicated in the aetiology of TD2M. If this holds true, what should happen from the epidemiological and public health point of view? A brief description of a few consequences of this hypothesis follows:

(a) Since the main source of vitamin D is skin production after UVB light exposure (Holick, 2004a), a seasonality effect on T2DM incidence should have to be observed. This has been reported in a registry study on T2DM incidence in Sweden during a 5-year period, in which a higher incidence was observed during the winter months (Berger et al. 1999);

(b) Risk of T2DM will have to increase by age, since there is an age-related decrease in vitamin $\mathrm{D}$ skin production (Holick, 2004b). It is a well-known fact that T2DM risk increases with age (Centers for Disease Control and Prevention, 2003);

(c) Risk of T2DM should be higher in individuals with highly-pigmented skin, compared with individuals with little skin pigmentation, since dark skin absorbs less UVB light and then is less able to synthesise vitamin D (Holick, 2004a). This also has been observed (Zittermann, 2003). However, an association between vitamin D status and insulin resistance was not observed in African-Americans in the NHANES study (Scragg et al. 2004);

(d) Impairment of vitamin D action - for example, by the presence of VDR gene polymorphisms - should have to be related to a higher risk of T2DM. VDR gene polymorphisms - particularly TaqI, BsmI, ApaI and FokI - have been associated with insulin resistance and T2DM in different populations (Chiu et al. 2001b; Ogunkolade et al. 2002; Oh \& Barrett-Connor, 2002). However, findings on this respect are still inconclusive.

Finally, vitamin D deficiency has been called an 'unrecognised epidemic' in the USA (Holick, 2004a), 
while at the same time there is growing evidence implicating vitamin $\mathrm{D}$ status in a number of chronic ailments, as autoimmune disease, cancers and CVD (Holick, 2004a; Raiten \& Picciano, 2004). Moreover, current vitamin D recommendations - which were originally set to prevent rickets (Vieth, 1999) - are likely to be reviewed soon (Weaver \& Fleet, 2004). All this guarantees an increasing interest in the role of vitamin $\mathrm{D}$ on health in the near future. In this respect, the need for carefully designed studies, with clearly defined outcomes and accurate measures of vitamin D status, as well as the study of possible mechanisms, cannot be overemphasised.

\section{Acknowledgements}

The author would like to thank Ellison Medical/International Nutrition Foundation (EM/INF) at Boston, USA, for a scholarship which made this work possible. I would like to give special thanks to Luz María de Regil for insightful comments.

\section{References}

Adorini L (2003) Tolerogenic dendritic cells induced by vitamin D receptor ligands enhance regulatory $\mathrm{T}$ cells inhibiting autoimmune diabetes. Annals of the New York Academy of Sciences 987, 258-261.

Arroyo CM, Kan RK, Burman DL, Kahler DW, Nelson MR, Corun CM, Guzman JJ \& Broomfield CA (2003) Regulation of 1- $\alpha, 25$-dihydroxyvitamin $\mathrm{D}_{3}$ on interleukin- 6 and interleukin- 8 induced by sulfur mustard (HD) on human skin cells. Pharmacology and Toxicology 92, 204-213.

Arunabh S, Pollack S, Yeh J \& Aloia JF (2003) Body fat content and 25-hydroxyvitamin D levels in healthy women. Journal of Clinical Endocrinology and Metabolism 88, 157-161.

Barzilay JL, Abraham L, Heckbert SR, Cushman M, Kuller LH, Resnick HE \& Tracy RP (2001) The relation of markers of inflammation to the development of glucose disorders in the elderly: the Cardiovascular Health Study. Diabetes 50, 2384-2389.

Bays H, Mandarino L \& DeFronzo RA (2004) Role of the adipocyte, free fatty acids, and ectopic fat in pathogenesis of type 2 diabetes mellitus: peroxisomal proliferator-activated receptor agonists provide a rational therapeutic approach. Journal of Clinical Endocrinology and Metabolism 89, 463-478.

Becker BN, Hullet DA, O'Herrin JK, Malin G, Sollinger HW \& DeLuca H (2002) Vitamin D as immunomodulatory therapy for kidney transplantation. Transplantation 74, 1204-1206.

Berger B, Stenstrom G \& Sundkvist G (1999) Incidence, prevalence, and mortality of diabetes in a large population: a report from the Skaraborg Diabetes Registry. Diabetes Care 22, 773-777.

Bermudez EA, Rifai N, Buring J, Manson JA \& Ridker PM (2002) Interrelationships among circulating interleukin-6, C-reactive protein, and traditional cardiovascular risk factors in women. Arteriosclerosis, Thrombosis and Vascular Biology 22, $1668-1673$.

Beutler B, Mahoney J, Le Trang N, Pekala P \& Cerami A (1985) Purification of cachectin, a lipoprotein lipase-suppressing hormone secreted by endotoxin-induced RAW 264. Journal of Experimental Medicine 161, 984-995.
Beutler BA \& Cerami A (1985) Recombinant interleukin 1 suppresses lipoprotein lipase activity in 3T3-L1 cells. Journal of Immunology 135, 3969-3971.

Borissova AM, Tankova T, Kirilov G, Dakovska L \& Kovacheva R (2003) The effect of vitamin D3 on insulin secretion and peripheral insulin sensitivity in type 2 diabetic patients. International Journal of Clinical Practice 57, 258-261.

Boucher BJ, Mannan N, Noonan K, Hales CN \& Evans SJ (1995) Glucose intolerance and impairment of insulin secretion in relation to vitamin D deficiency in east London Asians. Diabetologia 38, 1239-1245.

Cantorna MT, Zhu Y, Froicu M \& Wittke A (2004) Vitamin D status, 1,25-dihydroxyvitamin D3, and the immune system. American Journal of Clinical Nutrition 80, Suppl., 1717S-1720S.

Centers for Disease Control and Prevention (2003) National Diabetes Fact Sheet: General Information and National Estimates on Diabetes in the United States, 2002. Atlanta, GA: Department of Health and Human Services, Centers for Disease Control and Prevention, http://www.diabetes.org/ diabetes-statistics/national-diabetes-fact-sheet.jsp

Cheung AT, Ree D, Kolls JK, Fuselier J, Coy DH \& Bryer-Ash M (1998) An in vivo model for elucidation of the mechanism of tumor necrosis factor- $\alpha$ (TNF- $\alpha$ )-induced insulin resistance: evidence for differential regulation of insulin signaling by TNF- $\alpha$. Endocrinology 139, 4928-4935.

Chiu KC, Chu A, Go VLW \& Saad MF (2004) Hypovitaminosis D is associated with insulin resistance and $\beta$ cell dysfunction. American Journal of Clinical Nutrition 79, 820-825.

Chiu KC, Chuang L-M, Martinez DS \& Yoon C (2001a) Serum 25-hydroxyvitamin D concentration is a key determinant for insulin sensitivity. Diabetes 50, A512.

Chiu KC, Chuang L-M, Yoon C \& Chu A (2001b) The impact of the FokI polymorphism at the vitamin D receptor gene on insulin sensitivity and beta cell function. Diabetes 50, Suppl. 2, A234.

Das UN (2001) Is obesity an inflammatory condition? Nutrition 17, 953-966.

DeLuca HF \& Zierold C (1998) Mechanisms and functions of vitamin D. Nutrition Reviews 56, S4-S10.

Engström G, Stavenow L, Hedblad B, Lind P, Eriksson KF, Janzon L \& Lindgarde F (2003) Inflammation-sensitive plasma proteins, diabetes, and mortality of myocardial infarction and stroke: a population-based study. Diabetes 52, 442-447.

Esposito K, Pontillo A, Giugliano F, Giugliano G, Marfella R, Nicoletti G \& Giugliano D (2003) Association of low interleukin-10 levels with the metabolic syndrome in obese women. Journal of Clinical Endocrinology and Metabolism $\mathbf{8 8}$ $1055-1058$

Fernandez-Real JM, Broch M, Vendrell J \& Rieart W (2000) Interleukin-6 gene polymorphism and lipid abnormalities in healthy subjects. Journal of Clinical Endocrinology and Metabolism 85, 1334-1339.

Ford ES (2002) Leukocyte count, erythrocyte sedimentation rate, and diabetes incidence in a national sample of US adults. American Journal of Epidemiology 155, 57-64.

Freeman DJ, Norrie J, Caslake MJ, Gaw A, Ford I, Lowe GD, O'Reilly DS, Packard CJ Sattar N \& West of Scotland Coronary Prevention Study (2002) C-reactive protein is an independent predictor of risk of the development of diabetes in the West of Scotland Coronary Prevention Study. Diabetes 51, 1596-1600.

Freeman DJ, Norrie J, Sattar N, Neely RD, Cobbe SM, Ford I, Isles C, Lorimer AR, Macfarlane PW, McKillop JH, Packard CJ, Shepherd J, et al. (2001) Pravastatin and the development of diabetes mellitus: evidence for a protective treatment effect in the West of Scotland Coronary Prevention Study. Circulation 103, 357-362. 
Gewurz H, Zhang XH \& Lint TF (1995) Structure and function of the pentraxins. Current Opinion in Immunology 7, 54-64.

Han TS, Sattar N, Williams K, González-Villalpando C, Lean ME \& Haffner SM (2002) Prospective study of C-reactive protein in relation to the development of diabetes and metabolic syndrome in the Mexico City Diabetes Study. Diabetes Care 25, 2016-2021.

Harant H, Spinner D, Reddy GS \& Lindley IJ (2000) Natural metabolites of 1-alpha, 25-dihydroxyvitamin D3 retain biologic activity mediated through the vitamin D receptor. Journal of Cellular Biochemistry 78, 112-120.

Harant H, Wolff B \& Lindley IJ (1998) 1-Alpha, 25-dihydroxyvitamin D3 decreases DNA binding of nuclear factor-kappaB in human fibroblasts. FEBS Letters 436, 239-334.

Hewison M, Zehnder D, Chakraverty R \& Adams JS (2004) Vitamin D and barrier function: a novel role for extra-renal $1 \alpha-$ hydroxylase. Molecular and Cellular Endocrinology 215, $31-38$.

Higashimori T, Kim H-J, Choi H, Liu Z-X, Dong J, Kim Y-K, Noh H-L, Kim Y-B \& Jason K (2003) Interleukin-6 induces insulin resistance in skeletal muscle and liver in vivo. Diabetes 52, A422.

Holick MF (2004a) Sunlight and vitamin D for bone health and prevention of autoimmune diseases, cancers, and cardiovascular disease. American Journal of Clinical Nutrition 80, Suppl., $1678 \mathrm{~S}-1688 \mathrm{~S}$

Holick MF (2004b) Vitamin D: importance in the prevention of cancers, type 1 diabetes, heart disease, and osteoporosis. American Journal of Clinical Nutrition 79, 362-371.

Hundal RS, Petersen KF, Mayerson AB, Randhawa PS, Inzucchi S, Shoelson SE \& Shulman GI (2002) Mechanism by which high-dose aspirin improves glucose metabolism in type 2 diabetes. Journal of Clinical Investigation 109, 1321-1326.

Isaia G, Giorgino R \& Adami S (2001) High prevalence of hypovitaminosis D in female type 2 diabetic population. Diabetes 24, 1496.

Ishimura E, Nishizawa Y, Koyama H, Shoji S, Inaba M \& Morii H (1995) Impaired vitamin D metabolism and reponse in spontaneously diabetic GK rats. Mineral and Electrolyte Metabolism 21, 205-210.

Jiang C, Ting AT \& Seed B (1998) PPAR-gamma agonists inhibit production of monocyte inflammatory cytokines. Nature 391, 82-86.

Kadowaki S \& Norman AW (1985) Demonstration that the vitamin $\mathrm{D}$ metabolite $1,25(\mathrm{OH}) 2-\mathrm{D} 3$ and not $24 \mathrm{R}, 25(\mathrm{OH}) 2-\mathrm{D} 3$ is essential for normal insulin secretion in the perfused rat pancreas. Diabetes 34, 315-320.

Kershaw EE \& Flier JS (2004) Adipose tissue as an endocrine organ. Journal of Clinical Endocrinology and Metabolism 89, 2548-2556.

Kim H-J, Higashimori T, Choi H, Liu Z-X, Dong J, Kim Y-K, Noh H-L, Kim Y-B \& Jason K (2003) Pre-treatment of interleukin-10 prevents lipid-induced and interleukin-6-induced insulin resistance in vivo. Diabetes 52, A290.

Klover P, Zimmers T, Koniaris L \& Mooney RA (2003) Acute or chronic exposure to interleukin-6 induces hepatic insulin resistance in vivo. Diabetes 52, A290.

Koj A, Magielska-Zero D, Bereta J, Kurdowska A, Rokita H \& Gauldie J (1988) The cascade of inflammatory cytokines regulating synthesis of acute phase proteins. Journal of Experimental Medicine 13, 255-264.

Lagraine C \& Lebranchu Y (2003) Effects of immunosupressive drugs on dendritic cells and tolerance induction. Transplantation $\mathbf{7 5}, 37 \mathrm{~S}-42 \mathrm{~S}$.

Lemire JM (1995) Immunomodulatory actions of 1,25-dihydroxivitamin D3. Journal of Steroid Biochemistry and Molecular Biology 53, 599.
Lemire JM, Archer DC, Beck L \& Spiegelberg HL (1995) Immunosuppressive actions of 1,25-dihydroxyvitamin D3: preferential inhibition of Th1 functions. Journal of Nutrition 125, 1704S-1708S.

Long KZ \& Santos JI (1999) Vitamins and the regulation of the immune response. Pediatric Infectious Disease Journal 18, 283-290.

Mahon BD, Wittke A, Weaver V \& Cantorna MT (2003) The targets of vitamin $\mathrm{D}$ depend on the differentiation and activation status of CD4 positive T cells. Journal of Cellular Biochemistry 89, 922-932.

Matheu V, Back O, Mondoc E \& Issazadeh-Navikas S (2003) Dual effects of vitamin D-induced alteration of Th1/Th2 cytokine expression: enhancing $\operatorname{IgE}$ production and decreasing airway eosinophilia in murine allergic airway disease. Journal of Allergy and Clinical Immunology 112, 585-592.

Mathieu C, Jos L, Halina S, Michel V, Mark W \& Roger B (1992) 1,25-dihydroxivitamin D3 prevents insulitis in NOD mice. Diabetes 41, 1491-1495.

O'Kelly J, Hisatake J, Hisatake Y, Bishop J, Norman A \& Koeffler HP (2002) Normal myelopoiesis but abnormal T lymphocyte responses in vitamin D receptor knockout mice. Journal of Clinical Investigation 109, 1091-1099.

Ogunkolade B-J, Boucher B, Prahl JM, Bustin SA, Burrin JM, Noonan K, North BV, Mannan N, McDermott MF, DeLuca HF \& Hitman GA (2002) Vitamin D receptor (VDR) mRNA and protein levels in relation to vitamin D status, insulin secretory capacity, and VDR genotype in Bangladeshi Asians. Diabetes 51, 2294-2300.

Oh JY \& Barrett-Connor E (2002) Association between vitamin D receptor polymorphism and type 2 diabetes or metabolic syndrome in community-dwelling older adults: the Rancho Bernardo Study. Metabolism 51, 356-359.

Papanicolaou D (2000) Editorial: Interleukin-6: the endocrine cytokine. Journal of Clinical Endocrinology and Metabolism 85, $1331-1333$.

Parikh S, Edelman M, Semega-Janneh M, Freedman R, Calis K \& Yanovski J (2003) Relationships between calcitropic hormones and measures of insulin sensitivity in overweight adults. Diabetes 52, A293.

Parikh SJ, Edelman M, Uwaifo GI, Freedman RJ, Semega-Janneh M, Reynolds J \& Yanovski JA (2004) The relationship between obesity and serum 1,25-dihydroxy vitamin D concentrations in healthy adults. Journal of Clinical Endocrinology and Metabolism 89, 1196-1199.

Pepys MB \& Hirschfield GM (2003) C-reactive protein: a critical update. Journal of Clinical Investigation 111, 1805-1812.

Pichler J, Gerstmayr M, Szepfalusi Z, Urbanek R, Peterlik M \& Willheim M (2002) $1 \alpha, 25(\mathrm{OH}) 2 \mathrm{D} 3$ inhibits not only Th1 but also Th2 differentiation in human cord blood T cells. Pediatric Research 52, 12-18.

Pickup JC (2004) Inflammation and activated innate immunity in the pathogenesis of type 2 diabetes mellitus. Diabetes Care 27, 813-823.

Pittas A, Joseph NA \& Greenberg A (2004) Adipocytokines and insulin resistance. Journal of Clinical Endocrinology and Metabolism 89, 447-452.

Pradhan AD, Manson JE, Rifai N, Buring JE \& Ridker PM (2001) C-reactive protein, interleukin 6 , and risk of developing type 2 diabetes mellitus. JAMA 286, 327-334.

Raiten DJ \& Picciano MF (2004) Vitamin D and health in the 21st century: bone and beyond. Executive summary. American Journal of Clinical Nutrition 80, Suppl., 1673S-1677S.

Reaven GM (1988) Role of insulin resistance in human disease. Diabetes 37, 1595-1607.

Rotter V, Nagaev I \& Smith U (2003) Interleukin-6 (IL-6) reduces gene and protein expression of IRS-1 and GLUT4 and is 
overexpressed in human fat cells from insulin-resistant subjects. Diabetes 51, A303.

Schmidt MI, Duncan BB, Sharrett AR, Lindberg G, Savage PJ, Offenbacher S, Azambuja MI, Tracy RP \& Heiss G (1999) Markers of inflammation and prediction of diabetes mellitus in adults (Atherosclerosis Risk in Communities study): a cohort study. Lancet 353, 1649-1652.

Scragg R, Sowers M \& Bell C (2004) Serum 25-hydroxivitamin D, diabetes, and ethnicity in the Third National Health and Nutrition Examination Survey. Diabetes Care 27, 2813-2818.

Senn JJ, Klover PJ, Nowak IA \& Mooney RA (2002) Interleukin-6 induces cellular insulin-resistance in hepatocytes. Diabetes 51, $3391-3399$

Smith JK, Dykes R, Douglas JE, Krishnaswami G \& Berk S (1999) Long-term exercise and atherogenic activity of blood mononuclear cells in persons at risk of developing ischemic heart disease. JAMA 281, 1722-1727.

Stevenson MA, Zhao MJ, Asea A, Coleman CN \& Calderwood SK (1999) Salicylic acid and aspirin inhibit the activity of RSK2 kinase and repress RSK2-dependent transcription of cyclic AMP response element binding protein- and NF-[kappa]B-responsive genes. Journal of Immunology 163, 5608-5616.

Timms PM, Mannan N, Hitman GA, Noonan K, Mills PG, Syndercombe-Court D, Aganna E, Price CP \& Boucher BJ (2002) Circulating MMP9, vitamin D and variation in the TIMP-1 response with VDR genotype: mechanisms for inflammatory damage in chronic disorders? QJM 95, 787-796.

Tracey KJ \& Cerami A (1990) Metabolic responses to cachectin/TNF: a brief review. Annals of the New York Academy of Sciences 587, 325-331.

Vieth R (1999) Vitamin D supplementation, 25-hydroxyvitamin D concentrations, and safety. American Journal of Clinical Nutrition 69, 842-856.

Vozarova B, Weyer C, Lindsay RS, Pratley RE, Bogardus C \& Tataranni PA (2002) High white blood cell count is associated with a worsening of insulin sensitivity and predicts the development of type 2 diabetes. Diabetes 51, 455-461.

Weaver CM \& Fleet JC (2004) Vitamin D requirements: current and future. American Journal of Clinical Nutrition 80, Suppl., 1735S-1739S

Weisberg SP, McCann D, Desai M, Rosenbaum M, Leibel RL \& Ferrante AW (2003) Obesity is associated with macrophage accumulation in adipose tissue. Journal of Clinical Investigation 112, 1796-1808.

Worstman J, Matsuoka LY, Chen TC, Lu Z \& Holick MF (2000) Decreased bioavailability of vitamin D in obesity. American Journal of Clinical Nutrition 72, 690-693.

Xu H, Barnes GT, Yang Q, Tan G, Yang D, Chou CJ, Sole J, Nichols A, Ross JS, Tartaglia LA \& Chen H (2003) Chronic inflammation in fat plays a crucial role in the development of obesity-related insulin resistance. Journal of Clinical Investigation 112, 1821-1830.

Yuan M, Kostantopoulos N, Lee J, Hansen L, Li ZW, Karin M \& Shoelson SE (2001) Reversal of obesity and diet-induced insulin resitance with salicylates or targeted disruption of Ikkbeta. Science 293, 1673-1677.

Yudkin JS, Stehouwer CD, Emeis JJ \& Coppack SW (1999) C-reactive protein in healthy subjects: associations with obesity, insulin resistance, and endothelial dysfunction. A potential role for cytokines originating from adipose tissue? Arteriosclerosis, Thrombosis and Vascular Biology 19, 972-978.

Yusuf S, Sleight P, Pogue J, Davies R \& Dagenais G (2000) Effects of an angiotensin-converting-enzyme inhibitor, ramipril, on cardiovascular events in high-risk patients: the Heart Outcomes Prevention Evaluation Study Investigators. New England Journal of Medicine 342, 145-153.

Zittermann A (2003) Vitamin D in preventive medicine: are we ignoring the evidence? British Journal of Nutrition 89 , $552-572$. 